\title{
MODELLING VOLATILITY SPILLOVER BETWEEN CONVENTIONAL AND ISLAMIC STOCK INDEX IN MALAYSIA
}

Original scientific paper

\section{Edin Djedović ${ }^{1}$ \\ Ugur Ergun \\ Irfan Djedović}

Cantonal Administration for Inspection Affairs of Tuzla canton, Bosnia and Herzegovina Epoka University, Albania

International Burch University, Bosnia and Herzegovina

Received: $7 / 18 / 2020$

Accepted: 8/27/2020

\begin{abstract}
This paper analyzes the vollatility spillover between the conventional index in Malaysia FTSE Malaysia KLCI (KLSE) and the Islamic index in Malaysia FTSE Bursa Malaysia Shariah Index (FTFBMHS). Monthly observations spanning in a period from 2002 to 2018 are obtained from investing.com database. GARCH model and Johansen cointegration test are used to investigate volatility spillover and the relationship between two indices. The results of the analysis indicate that in the short-run there is volatility spillover between FTSE Malaysia KLCI and FTSE Bursa Malaysia Shariah Index, while in the long-run there is no relationship between the two indices. The methodology of compiling Islamic indeces is based on Shariah law.
\end{abstract}

Keywords: Conventional stock market index, Islamic stock market index, Malaysia, Shariah law, volatility.

\footnotetext{
${ }^{1}$ Correspondence to:

Edin Djedović, Cantonal Administration for Inspection Affairs of Tuzla canton, Bosnia and Herzegovina

Bosnia and Herzegovina

Phone:+38761 731129

E-mail: e_djedovich@hotmail.com
} 


\section{INTRODUCTION}

In the last three decades we can witness that Islamic financial services around the world have a rapid growth. If we focus on Islamic stock market indices, it can be seen that the most important global stock market index providers have introduced Islamic stock market indices. Based on this fact we are witnessing that many countries have Islamic stock market indices as an option for investors. Besides the most important and developed financial centers some developing countries such are Malaysia, Turkey, Indonesia, Saudi Arabia, etc. have introduced Islamic stock market indices.

These indices and Islamic financial instruments are based on the Shariah law, and therefore they are acceptable from the Islamic perspective. Financial law and its legal provisions in this context is based on the legal norms of the Shariah law, which regulates the legal basis of the matter of financial relations, the legal justification of these relations, and defines the application of existing legal norms. The methodology of compiling Islamic indeces itself is based on Shariah law.

Islamic indices can be a good option for all type of investors. This is a way for diversification of investor's portfolio. Furthermore, this is very important option for investors who want to invest based on their religious beliefs. Therefore, we can state that the introduction of Islamic stock market indices is a kind of response to this type of investors' needs. As Ho, Rahman, Yusuf and Zamzamin (2013) suggest "the markets for both conventional and ethics-filtered investments have developed rapidly as new investment instruments over the last two decades. These investments have not only expanded in the conventional capital and money markets but also in the recently-developing Islamic financial markets. Over the past decade, the global capital market scene has witnessed the introduction of Islamic indices, which are designed to filter out the stocks in conventional indices in accordance with the doctrinal position of Islamic laws that introduces a number of ethical considerations for an instrument to be considered as ethically-acceptable. Some of the indices are: Financial Times Islamic Index Series (FTSE), Dow Jones Islamic Market Index (DJIM)".
Furthermore, Ho, Rahman, Yusufand Zamzamin (2013) mention that "the dedication shown by the global index providers to offer Islamic indices has provided evidence that Islamic investors are showing greater selectivity in their investment choices. Global index providers have shaped these new indices in slightly different ways to take into account different expectations of regulators of both Islamic and conventional markets. It is interesting to note that there has been tremendous interest in Shari'ah compliant investments and indices, mainly due to their more equitable and profit-sharing nature, which draws considerable research interest in recent years.

Abdullah, Roudaki and Clark (2010) sugest that for investors, more precisely Muslim investors, it is important to have the list of Shariah-compliant stock, because it gives to the investors neccessary opportunity and confidence to select and invest in the listed companies that comply with the Shariah principles.

Based on the introduction words, we can state that Islamic stock market indices are very important area for researchers. Therefore, knowing behavior, movements and factors that have influence on Islamic indices is very important topic.

Furthermore, since Islamic stock market indices differ from the ordinary conventional indices, beacuse they are "filtered version", it is valuable and interesting to see how these indices respond to their conventional counterpart indices movement. (Djedovic \& Ergun, 2018)

It is considered that macroeconomic variables cannot comprise all the information available to the capital market, while stock prices react quickly to publicly disclosed information. Therefore, it is recommended and important to investigate how financial markets variables effect on a stock market index. Therefore, in this study we focus on financial markets variable represented through counterpart conventional stock market index, and its impact on the Islamic stock market index.

This study is focused on the relationship and eventual volatility spillover from the conventional stock market index in Malaysia to the Islamic stock market index in Malaysia. It is important to mention that Malaysia is one of the leading countries in Islamic finance, and 
that there is a developed Islamic financial system in that country. The results of the analysis indicate that in the short-run there is volatility spillover between FTSE Malaysia KLCI and FTSE Bursa Malaysia Shariah Index, while in the long-run there is no relationship between the conventional and the Islamic index in Malaysia.

\section{LITERATURE REVIEW}

The literature investigating behavior of the Islamic stock market indices is still developing. In this way we are contributing to the present literature through analysis of volatility spillover between between the conventional and the Islamic index in Malaysia.

Djedovic and Ergun (2018) investigated volatility spillover between conventional and Islamic index in the UK. They used monthly observations from 2010 to 2017. By using vector auto-regression analysis and impulse response functions they found a significant impact of Dow Jones UK index volatility on Dow Jones UK Islamic index volatility.

Hkiri et al. (2017) in their study examine directional and net volatility spillovers between conventional and Islamic indexes and importance of crisis periods. Their study covers nine regional Islamic stock indexes and their conventional counterparts, using the generalized vector autoregressive framework. Daily data covering the period 1999 to 2014 is used.

Their results show that global financial crises strongly affect the cross-market volatility. Although the contagion hypothesis is evident for both Islamic and conventional indexes, the findings also suggest the presence of a decoupling of the Islamic indexes from their conventional counterparts during turbulent periods. The results confirm that the Islamic financial indexes are a safe haven for investors during financial crises. Furthermore, paper reports significant timevarying patterns in the volatility spillovers for all the Islamic and conventional stock indexes and points out the stress transmitters and receivers.
Jebran, Chenb and Tauni (2017) in their study focusing on Pakistan found significant long run and short run association between Islamic and conventional index. Furthermore, the study finds asymmetric bidirectional volatility spillover between Islamic and conventional index.

Saadaoui and Boujelbene (2015) examined volatility transmission between Dow Jones Stock Index and Emerging Islamic Stock Index. They used daily data from 2005 to 2012. Based on vicariate BEKKGARCH and DCC-GARCH model, their result shows that there is a transmission mainly during the crisis period which means that the crisis affects all the financial assets whether Islamic or not.

Majdoub and Mansour (2014) find weak correlation between US and five Islamic emerging equity markets over time.

Based on several previous research it can be stated that there are mixed results regarding volatility spillover between conventional and Islamic stock market indices.

\section{DATA AND METHODOLOGY}

In the study used are monthly observations of FTSE Malaysia KLCI (KLSE) and FTSE Bursa Malaysia Shariah Index (FTFBMHS). The period that is covered in the study is spanning from 2002 to 2018. The data is obtained from investing.com database.

GARCH analysis is used to estimate short-run impact of conventional index on the islamic index. Furthermore, Johansen cointegration test is used in order to estimate the long -run relationship between the two observed indices.

The arithmetic return of the indices was estimated by subtracting the index value at time $t-1$ from the index value at time $t$ and dividing it by the index value at time $t$ as shown in Eq. (1), where $\mathrm{Rt}$ is the return at time $t, P t$ is the index at time $t$, and Pt- 1 is the index at time $\mathrm{t}-1$.

Equation 1. $\quad \mathrm{R}_{\mathrm{t}}=\left(\mathrm{P}_{\mathrm{t}}-\mathrm{P}_{\mathrm{t}^{-} 1}\right) / \mathrm{P}_{\mathrm{t}^{-}}$ 
The next step was the calculation of the volatility of both indices. Volatility was measured as a square of the deviations from the mean. We considered that $\boldsymbol{\Delta} \boldsymbol{y}_{\boldsymbol{t}}$ indicates the series with deviations from the means. As it can be seen in Eq (2), the volatility of the indices was estimated as:

$$
\begin{aligned}
& \text { Equation 2. } \Delta y_{t}^{2}=\left(\Delta y_{t}-\Delta \bar{y}\right)^{2} \\
& \Delta y_{t}^{2}=\left(\Delta y_{t}-\Delta \bar{y}\right)^{2} \\
& \text { where } \boldsymbol{\Delta} \bar{y}=\frac{\sum \Delta y_{t}}{T} \Delta \bar{y}=\frac{\sum \Delta y_{t}}{T} \text {. }
\end{aligned}
$$

\section{EMPIRICAL ANALYSIS AND RESULTS}

This part of the study presents the graphs representing the movement of the two indices (price, return and volatility) over time. Furthermore, it brings the unit root tests for the time series used in the analysis, as well as the results of GARCH and Johansen cointegration test analysis.

\section{ADF Unit Root Test}

Table 1. Unit root test for Malaysian stock market prices (growth rates)

\begin{tabular}{lcc}
\hline & \multicolumn{2}{c}{ Test Statistics } \\
\hline Variables & Level & 1st Difference \\
\hline GFTSECON $^{1}$ & $-11,364630^{*}$ & \\
GFTSEISL $^{1}$ & $-7.370 .217^{*}$ & \\
\hline
\end{tabular}

Note: ${ }^{1},{ }^{2}$ Indicates Augmented Dickey-Fuller test and Phillips-Perron test respectively, * indicates the series is stationary at $1 \%$ significance level

Source: Author's own work

Table 1. represents the results of unit root test for stock market indices growth rates in Malaysia.
Table 2. Unit root test - Volatility of stock market indices in Malaysia

\begin{tabular}{lcc}
\hline & \multicolumn{2}{c}{ Test Statistics } \\
\hline Variables & Level & 1st Difference \\
\hline VOLISL $^{1}$ & $-2,063.802$ & $-11,892820^{*}$ \\
VOLCON $^{1}$ & $-2,191.664$ & $-11,361280^{*}$ \\
VOLGISL $^{1}$ & $-10,893910^{*}$ & \\
VOLGCON $^{1}$ & $-11,758300^{*}$ & \\
\hline
\end{tabular}

Note: ${ }^{1}$ Indicates Augmented Dickey-Fuller test, * indicates the series is stationary at $1 \%$ significance level

Source: Author's own work

Table 2. represents the results of unit root test for volatility values of stock market indices in Malaysia.

\section{Graphical representation of the variables}

In this section, we present the prices, return and volatility values of the conventional index in Malaysia FTSE Malaysia KLCI (KLSE) and the Islamic index in Malaysia FTSE Bursa Malaysia Shariah Index, for the observed period of time.

In Figure 1. graphicaly are presented the prices of FTSE Bursa Malaysia Shariah index (FTFBMHS) and FTSE Malaysia KLCI (KLSE) index.
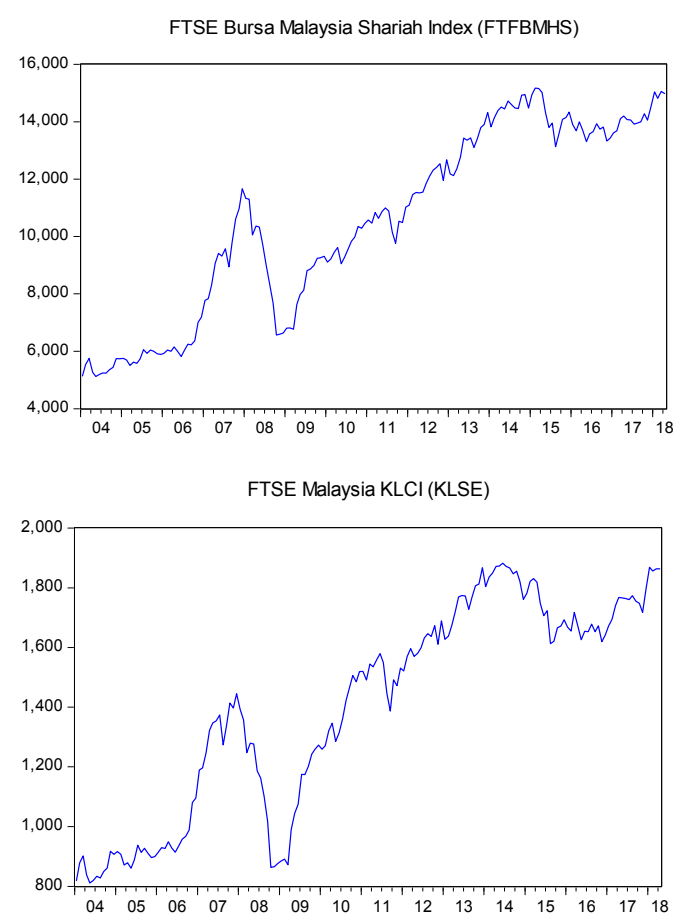

Figure 1. Islamic and conventional indices' prices Malaysia

Source: Author's own work 
In Figure 2. presented are return rates of the Islamic and the conventional index in Malaysia. The blue line is representing the Islamic index return rate, while the red line represents the conventional index return.

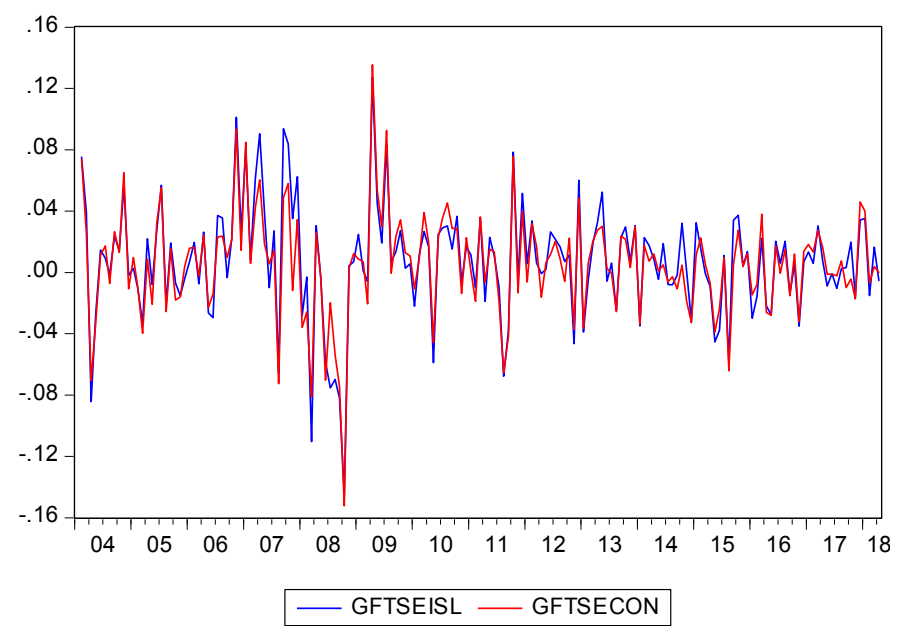

Figure 2. Islamic and conventional index return rates in Malaysia

Source: Author's own work
Figure 3. represents volatilities of the conventional index and the Islamic index in Malaysia. The blue line represents the volatility of the Islamic index, while the red line represents the volatility of the conventional index.

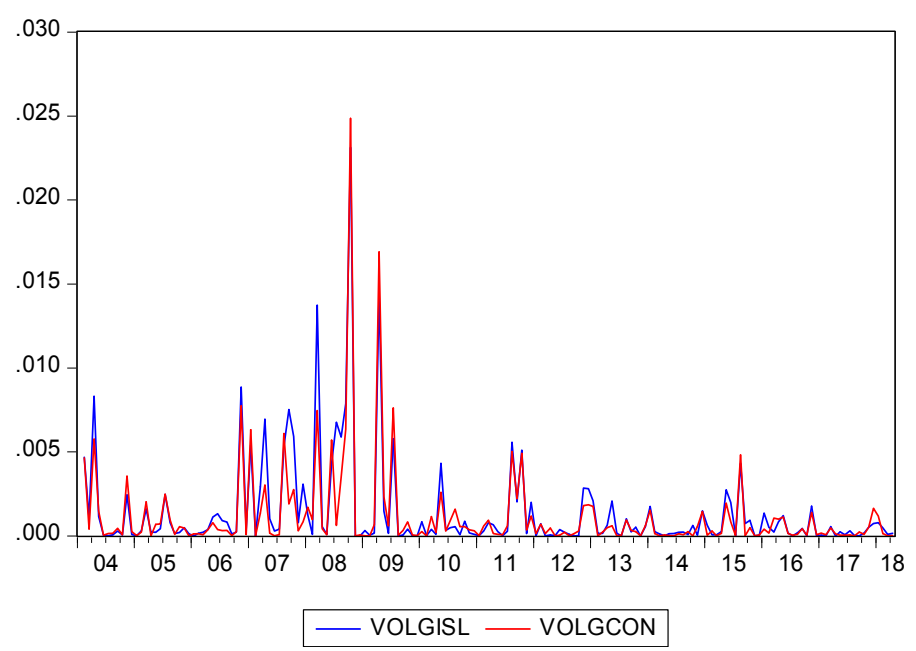

Figure 3. Islamic and conventional index volatility in Malaysia

Source: Author's own work

\section{GARCH analysis}

In this part of analysis we employ GARCH model in order to investigate short-run impact (volatility spillover) from the conventional index to the Islamic index in Malaysia.

The results of the analysis are presented in Table 3.

Table 3. Short-run impact of conventional index on Islamic index in Malaysia Dependent Variable: GMALISL

\begin{tabular}{lcccc}
\hline Variable & Coefficient & Std. Error & z-Statistic & Prob. \\
\hline GMALCON & 0.289639 & 0.017279 & 1.676 .285 & 0.0000 \\
VOLMALISL & -4.533 .967 & 2.992 .670 & -1.515 .024 & 0.1298 \\
VOLMALCON & 3.013 .558 & 1.810 .657 & 1.664 .345 & 0.0960 \\
C & 0.000179 & $3.22 \mathrm{E}-05$ & 5.552 .224 & 0.0000 \\
\hline \multicolumn{5}{c}{ Variance Equation } \\
\hline C & $5.16 \mathrm{E}-08$ & $3.86 \mathrm{E}-08$ & 1.335 .375 & 0.1818 \\
GESID(-1)^2 & 0.003244 & 0.002763 & 1.173 .847 & 0.2405 \\
GMALCON & -0.002468 & 0.001063 & -2.322 .265 & 0.0202 \\
VOLMALISL & $4.22 \mathrm{E}-06$ & $3.51 \mathrm{E}-05$ & 0.120295 & 0.9042 \\
VOLMALCON & 0.604191 & 0.058630 & 1.030 .507 & 0.0000 \\
\hline
\end{tabular}

GARCH $=\mathrm{C}(5)+\mathrm{C}(6) * \operatorname{RESID}(-1)^{\wedge} 2+\mathrm{C}(7) * \mathrm{GARCH}(-1)+\mathrm{C}(8)^{*} \mathrm{GMALCON}+\mathrm{C}(9) *$ VOLMALISL + C(10)*VOLMALCON

Source: Author's own work

The results form Table 3 . indicate that the conventional index return has significant positive short-run impact on the Islamic index return in Malaysia. Furthermore, from the variance equation it can be seen that volatility of conventional index have significant positive short- run impact on the Islamic index volatility in Malaysia. The results suggest that there is volatility spillover from the conventional to the Islamic stock market index in Malaysia. 
Malaysia. In order to investigate this relationship we employed Johansen cointegration test.

In this section investigated is the long-run relationship The results of the analysis are presented in Table 4. between the conventional and the Islamic index in

Table 4. Long-run relationship between conventional and Islamic index in Malaysia

\begin{tabular}{lccccccr}
\hline $\begin{array}{l}\text { Hypothesized } \\
\text { No. of CE(s) }\end{array}$ & Eigenvalue & $\begin{array}{c}\text { Trace } \\
\text { Statistic }\end{array}$ & $\begin{array}{c}\mathbf{0 . 0 5} \text { Critical } \\
\text { Value }\end{array}$ & Prob.** & $\begin{array}{c}\text { Max-Eigen } \\
\text { Statistic }\end{array}$ & $\begin{array}{c}\text { 0.05 Critical } \\
\text { Value }\end{array}$ & Prob.** \\
\hline None & 0.005180 & 1.297 .385 & 1.549 .471 & 0.1158 & 1.012 .808 & 1.426 .460 & 0.2037 \\
At most 1 & 0.001458 & 2.845 .772 & 3.841 .466 & 0.0916 & 2.845 .772 & 3.841 .466 & 0.0916 \\
\hline
\end{tabular}

Source: Author's own work

The results from Table 4. indicate that there is no cointegrating relationship between variables. This suggests that there is no long-run relationship between the conventional and the Islamic index in Malaysia.

\section{CONCLUSION AND DISCUSION}

The main purpose of this research was to investigate the existence of volatility spillover and the nature of the relationship between the conventional stock market index and the Islamic stock market index in Malaysia. The indices that were used for this purpose are Malaysia FTSE Malaysia KLCI (KLSE) which represents conventional index and FTSE Bursa Malaysia Shariah Index (FTFBMHS) which represents Islamic index in Malaysia.

In order to fulfill the research objective employed were GARCH model for short-term relationship, as well as Johansen cointegration test for long-run relationship. Based on the results, the following relationships can be highlighted.

The results from GARCH model indicate that conventional index return has significant positive impact on the Islamic index return in Malaysia. This result suggests that when the conventional index return in Malaysia is higher, then the Islamic index return in Malaysia is also higher. Furthermore, the results from the variance equation suggest that volatility of the conventional index in Malaysia has significant positive impact on the volatility of the Islamic index return in Malaysia. This suggests that the higher the volatility of the conventional index in Malaysia, the higher the volatility of the Islamic index return.
The results investigating long-run relationship among the two indices in the Malaysia indicate that there is no long-run relationship between the conventional and the Islamic index in Malaysia. This result suggests that in the long-run the Islamic index and the conventional index in Malaysia are not moving together.

In the end we can conclude that the movement of the Islamic index can be explained in short-run by using the conventional counterpart index, while in the longrun the Islamic index is moving independently from the conventional counterpart index.

This study contributes to the existing developing literature on the relationship between conventional and Islamic stock market indices in general. We can mention that since there are fundamental differences between Islamic and conventional financial assets, one might argue against the potential transmission of risk or volatility across Islamic and conventional equities. However, the results of the research indicate that there is volatility spillover from conventional index to Islamic index in the short-run. This suggests that Islamic index is not immune to the volatility changes of conventional index, meaning that since it is part of the integrated domestic market it cannot avoid short-run volatility impact coming from conventional counterpart index. The explanation for this could be found in the following argument. As Djedovic and Ergun (2018) mention, ,in a market economy, the value of a firm can be influenced both directly and indirectly. Also, Islamic scholars have made some concessions on the permissible degree of financial leverage and the level of interest income in relation to Islamic indices constituent firms. 
Thus, Islamic indices could be expected to be sensitive to conventional stock index changes".

Practical implication of this study for the investors is that in the long-run there is diversification opportunity when investing in the conventional or the Islamic index in Malaysia, since there is no long-run relationship between the conventional and the Islamic index in Malaysia.

\section{REFERENCES}

Abdullah, W.R.W., Roudaki, J., \& Clark, M. (2010). The evolution of the Islamic capital market in Malaysia; Accounting History International Conference on Accounting and the State, Wellington, New Zealand.

B. Hkiri, S. Hammoudeh, C. Aloui, L., \& Yarovaya (2017). Are islamic indexes a safe haven for investors? An analysis of total, directional and net volatility spillovers between conventional and islamic indexes and importance of crisis periods. Pacific-Basin Finance Journal, 43, 124-150.

Djedovic, I. \& Ergun, U. (2018). Modelling volatility spillover between conventional and Islamic stock index in the United Kingdom. Journal of Management, Economics, and Industrial Organization, 2(3), 1-17.

Ho, C.S.F., Rahman, N.A.A., Yusuf, N.H.M., \& Zamzamin, Z. (2013). Performance of global Islamic versus conventional share indices: International evidence. Pacific-Basin Finance Journal, 28, 110-121.

Jebran, K., Chen, S., \& Tauni, M.Z. (2017). Islamic and conventional equity index comovement and volatility transmission: Evidence from Pakistan. Future Business Journal, 3, 98-106.

Majdoub, J., \& Mansour, W. (2014). Islamic equity market integration and volatility spillover between emerging and US stock markets. The North American Journal of Economics and Finance, 29, 452-470.

Saadaoui, A. \& Boujelbene, Y. (2015). Volatility transmission between Dow Jones Stock Index and Emerging Islamic Stock Index: Case of subprime financial crises. Emerging Markets Journal, 5(1), 40-49.

https://www.investing.com, Accessed 3. May 2018. 